\title{
The genetic association between magnetite-hematite and porphyry copper deposits: Reply to Pokrovski
}

\author{
Wei-dong Sun ${ }^{\mathrm{a}, *}$, Chan-chan Zhang ${ }^{\mathrm{a}, \mathrm{c}}$, Hua-ying Liang ${ }^{\mathrm{a}, *}$, Ming-xing Ling ${ }^{\mathrm{b}}$, \\ Cong-ying Li $^{\mathrm{a}}$, Xing Ding ${ }^{\mathrm{b}}$, Hong Zhang ${ }^{\mathrm{b}}$, Xiao-yong Yang ${ }^{\mathrm{d}}$, Trevor Ireland ${ }^{\mathrm{e}}$, \\ Wei-ming Fan ${ }^{\text {b }}$ \\ ${ }^{a}$ Key Laboratory of Mineralogy and Metallogeny, Guangzhou Institute of Geochemistry, Chinese Academy of Sciences, 511 Kehua Street, \\ Wushan, Guangzhou 510640, China \\ ${ }^{\mathrm{b}}$ State Key Laboratory of Isotope Geochemistry, Guangzhou Institute of Geochemistry, Chinese Academy of Sciences, 511 Kehua Street, \\ Wushan, Guangzhou 510640, China \\ ${ }^{\mathrm{c}}$ University of the Chinese Academy of Sciences, Beijing 100049, China \\ ${ }^{\mathrm{d}}$ Key Laboratory of Crust-Mantle Materials and Environments, University of Science and Technology of China, Hefei 230026, China \\ ${ }^{\mathrm{e}}$ Research School of Earth Sciences, Australian National University, Canberra 0200, Australia
}

Received 23 May 2013; accepted in revised form 28 July 2013; available online 9 August 2013

Porphyry mineralization is a very complicated process with hundreds of different possible reactions. Sun et al. (2013) presented only several combined important reaction equations in order to make the paper more straightforward. Our response to Pokrovski's comment provides us with an opportunity to better explain the controlling factors and reactions of porphyry mineralization. The most important thing for understanding porphyry mineralization is that both magmas and fluids are involved in porphyry mineralization processes. Hydrothermal processes at temperatures between $550-350{ }^{\circ} \mathrm{C}$ are the most important for the final porphyry $\mathrm{Cu}$ mineralization (Sillitoe, 2010). Most of the reactions occurred in fluids and/or during fluid/rock interactions, which is not fully considered by Pokrovski (2013) and many others when discussing reactions responsible for porphyry mineralization (Zajacz et al., 2011, 2012). It must always be considered that reactions proposed may not mimic geological observations.

Hematite-magnetite intergrowths are common in essentially all large porphyry $\mathrm{Cu}-\mathrm{Au}$ deposits (Sillitoe, 2010; Sun et al., 2013). This has puzzled us for a while, because the ferrous/ferric ratio of magmas are usually much higher than that of magnetite, therefore the crystallization of magnetite would further increase the ferrous/ferric ratio and correspondingly tend to lower the oxidation fugacity of the parental magmas, under the same physical-chemical

\footnotetext{
* Corresponding authors. Tel.: +86 2085290215 (W.-d. Sun).

E-mail addresses: weidongsun@gig.ac.cn(W.-d. Sun), lianghy@, gig.ac.cn (H.-y. Liang).
}

conditions (Sun et al., 2004; Liang et al., 2009; Jenner et al., 2010). This is true for magmatic process when the $\mathrm{pH}$ value does not change much. After struggling with this problem for some time, we realized that the formation and further oxidation of magnetite are responsible for sulfate reduction controlled by $\mathrm{pH}$, which is the key process for the final mineralization.

It has long been recognized that magmas with high oxygen fugacity favors porphyry $\mathrm{Cu}$ mineralization (Ballard et al., 2002; Mungall, 2002; Liang et al., 2006, 2009; Sillitoe, 1997, 2010; Sun et al., 2010, 2011, 2012a,b; Zhang et al., 2013). Elements that exist in variable oxidation states and present in sufficient abundances to affect the redox state of the porphyry mineralization system, e.g., C, H and S, all establish oxygen fugacity lower than the HM buffer under standard conditions (Fig. 1) (Mungall, 2002). In contrast to FMQ, HM oxygen buffers (Fig. 1, Eqs. (3 and 4)), sulfur-related redox reactions are sensitive to $\mathrm{pH}$ and concentrations of species involved (Eqs. (1) and (5)), i.e., the oxidation potential of sulfate increases with decreasing $\mathrm{pH}$ values and $\mathrm{H}_{2} \mathrm{~S} / \mathrm{H}_{2} \mathrm{SO}_{4}$ (Eq. (1)). To catch up with progress in sulfur studies, we used the $\log \mathrm{fO}_{2}$ versus $\mathrm{pH}$ diagram for sulfur speciation of Pokrovski and Dubrovinsky (2011) to explain the effects of magnetite-hematite intergrowth on porphyry mineralization and the mechanism behind it (Sun et al., 2013). Although it is claimed that the trisulfur $\mathrm{S}_{3}{ }^{-}$ion has been demonstrated to be the dominant sulfur species at temperatures between $250-450{ }^{\circ} \mathrm{C}$, pressures between 5-35 kbar and $\mathrm{pH}$ of $1-7$, and is more stable at higher temperatures (Pokrovski and Dubrovinsky, 2011), 


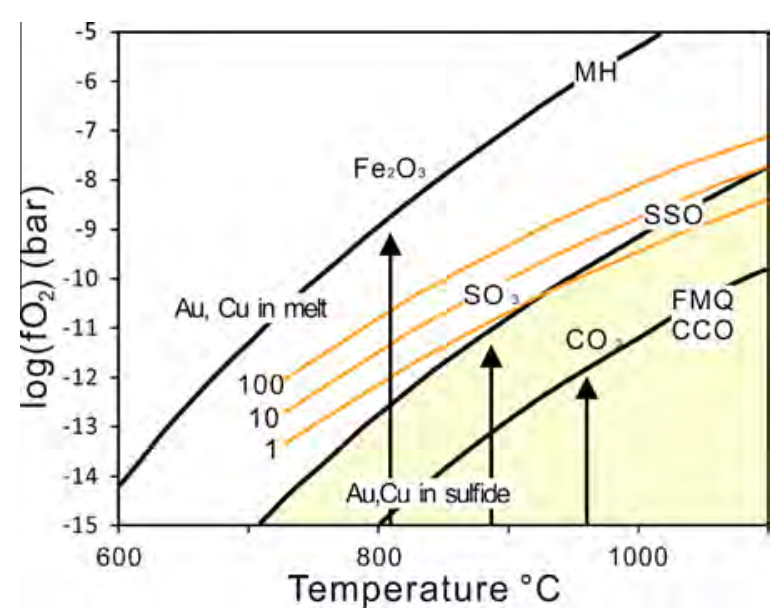

Fig. 1. Oxygen buffers in $\log \left(\mathrm{fO}_{2}\right)$ versus temperature (Matthews et al., 1994; Mungall, 2002). SSO-sulfide-sulfur oxide buffer (Eq. (1): $\mathrm{H}_{2} \mathrm{~S}+2 \mathrm{O}_{2}=\mathrm{H}_{2} \mathrm{SO}_{4}$ ); $\mathrm{CCO}$ - carbon dioxide-carbon oxide

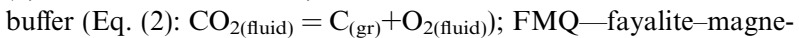
tite-quartz oxygen buffer (Eq. (3): $3 \mathrm{Fe}_{2} \mathrm{SiO}_{4}+\mathrm{O}_{2}=2 \mathrm{Fe}_{3} \mathrm{O}_{4}+$ $3 \mathrm{SiO}_{2}$ ); $\mathrm{MH}$ - magnetite-hematite oxygen buffer (Eq. (4): $4 \mathrm{Fe}_{3-}$ $\mathrm{O}_{4}+\mathrm{O}_{2}=6 \mathrm{Fe}_{2} \mathrm{O}_{3}$ ). Hematite-magnetite buffer is higher than SSO buffer and 1, 10, 100: $\mathrm{H}_{2} \mathrm{~S}-\mathrm{SO}_{2}$ (Eq. (5): $2 \mathrm{H}_{2} \mathrm{~S}+3 \mathrm{O}_{2}=2 \mathrm{H}_{2}$ $\mathrm{O}+2 \mathrm{SO}_{2}$ ) at 4 kbar, with $\mathrm{SO}_{2} / \mathrm{H}_{2} \mathrm{~S}$ ratios of 1,10 and 100 , respectively.

the published figure was applicable at $350^{\circ} \mathrm{C}$ and $5 \mathrm{kbar}$, which is slightly lower in temperature and higher in pressure than optimal porphyry mineralization conditions. We therefore wrote to Professor Pokrovski, asking whether it is indeed applicable under higher temperatures and lower pressures. Professor Pokrovski kindly replied with a positive answer and a diagram at $450{ }^{\circ} \mathrm{C}$ and $5 \mathrm{kbar}$ (not published), which is quite similar to that under lower temperatures. We therefore used the diagram at $350{ }^{\circ} \mathrm{C}$ and 5 kbar (Pokrovski and Dubrovinsky, 2011) to explain our model. While the diagram used in Sun et al. (2013) was an iron free system (Pokrovski and Dubrovinsky, 2011; Pokrovski, 2013), this is of no consequence because Fe reacts with $\mathrm{S}^{2-}$ forming pyrite, $\mathrm{H}_{2}$ and $\mathrm{H}^{+}$(Eq. (6)) (Heinrich, 1990), such that it promotes sulfate reduction and further elevates the oxidation potential of sulfate. Therefore, as shown by Eqs. (1) and (6), whether $\mathrm{S}_{3}{ }^{-}$is stable or not has no influence on our conclusion. The oxidation potential of sulfate increases during its reduction as a result of decreasing $\mathrm{pH}$ and $\mathrm{H}_{2} \mathrm{~S} / \mathrm{H}_{2} \mathrm{SO}_{4}$ (or $\mathrm{S}_{3}{ }^{-} / \mathrm{H}_{2} \mathrm{SO}_{4}$ ), which eventually reaches the HM buffer. For the same reason, the basic concepts of the phase diagram emphasized by Pokrovski (2013) are irrelevant to our model.

$\mathrm{FeCl}_{2}+2 \mathrm{H}_{2} \mathrm{~S}=\mathrm{FeS}_{2}+2 \mathrm{HCl}+\mathrm{H}_{2}$

$\mathrm{H}_{2}$ tends to escape from the porphyry system during degassing or infiltration, and may also further react with $\mathrm{CO}_{2}$ and/or $\mathrm{O}_{2}$ (Eqs. (7) and (8)).

$$
\begin{aligned}
& 4 \mathrm{H}_{2}+\mathrm{CO}_{2}=\mathrm{CH}_{4}+2 \mathrm{H}_{2} \mathrm{O} \\
& 2 \mathrm{H}_{2}+\mathrm{O}_{2}=2 \mathrm{H}_{2} \mathrm{O}
\end{aligned}
$$

Pokrovski (2013) claims that the reactions listed in (Sun et al., 2013) do not allow any definite constraint on the evolution of redox or $\mathrm{pH}$ conditions during porphyry deposit formation. However, all those reactions are combinations of 2 or more reactions. This also explains the apparent large number of electron transferred in these reactions (Sun et al., 2013). For example, Eq. (9) is a combination of two reactions (Eqs. (10) and (11)):

$$
\begin{aligned}
& 12 \mathrm{Fe}^{2+}+\mathrm{SO}_{4}^{2-}+12 \mathrm{H}_{2} \mathrm{O}=4 \mathrm{Fe}_{3} \mathrm{O}_{4}+\mathrm{HS}^{-}+23 \mathrm{H}^{+} \\
& 6 \mathrm{Fe}^{2+}+\mathrm{O}_{2}+6 \mathrm{H}_{2} \mathrm{O}=2 \mathrm{Fe}_{3} \mathrm{O}_{4}+12 \mathrm{H}^{+} \\
& \mathrm{SO}_{4}^{2-}+\mathrm{H}^{+}=\mathrm{HS}^{-}+2 \mathrm{O}_{2}
\end{aligned}
$$

Oxygen is divided out when Eqs. (10) and (11) are combined. This does not mean that those reactions have no control on redox conditions. Given that the oxygen fugacity of the FMQ buffer is much lower than that of the SSO reaction line at near-neutral condition (Fig. 1), the oxygen fugacity of the system is mainly controlled by SSO (Eq. (1)) before ferrous iron is consumed, i.e., the redox is controlled by the oxidation potential of sulfate (Eq. (11)), which increases with decreasing $\mathrm{pH}$ values. This is dramatically different for magmatic processes. Under magmatic conditions, $\mathrm{pH}$ does not change much. Crystallization of magnetite converts sulfate to sulfide, and lowers the oxygen fugacity of the system (Sun et al., 2004; Liang et al., 2009; Jenner et al., 2010). A similar process has been proposed to explain sulfate reduction during porphyry mineralization. In contrast to magmatic processes, $\mathrm{pH}$ value plays a big role in controlling the oxidation potential of sulfate during hydrothermal activities, i.e., the $\mathrm{pH}$ value decreases during sulfate reduction by magnetite, which elevated the oxidation potential of sulfate (Sun et al., 2013). Once ferrous iron concentration is lowered enough by magnetite crystallization, the oxygen fugacity is controlled by the magnetite-hematite buffer (Eq. (4)), which does not change with $\mathrm{pH}$. When both sulfate- $\mathrm{S}_{3}{ }^{-}$and hematite-magnetite buffers are active, the reactions occur near the intersection of $\mathrm{HM}$ and sulfate reduction lines. Note that although sulfate reduction lines change with relative activity ratios of species evolved, the slope, and thus the trend, does not change.

For the formation of magnetite, Pokrovski (2013) proposes an alternative reaction (Eq. (12)), and suggests that protons are consumed upon magnetite formation and there is thus a decrease in acidity (i.e., an increase in $\mathrm{pH}$ ) in the melt and the resulting exsolved fluid:

$$
\left.12 \mathrm{FeO}(\text { melt })+\mathrm{SO}_{4}^{2-}+2 \mathrm{H}^{+}=4 \mathrm{Fe}_{3} \mathrm{O}_{4} \text { (magnetite }\right)+\mathrm{H}_{2} \mathrm{~S}
$$

We would note that the magmatic system is complicated, while most readers prefer simplified reactions. We feel that the problem with the scheme proposed by Pokrovski is that he used oxides $(\mathrm{FeO})$ to react with acid $\left(\mathrm{H}_{2} \mathrm{SO}_{4}\right)$, and this certainly lowers the acidity. However, such a proposal is misleading. For the following reasons, we believe this reaction is inappropriate for porphyry mineralization. (1) Ferrous iron is mainly present in silicate minerals (salt, instead of oxide) in magmas and as $\mathrm{FeCl}_{2}$ in co-existing magmatic fluids, but not $\mathrm{FeO}$. The fluid phase is more reactive and important for porphyry mineralization, i.e., no fluids, no porphyry. "In many porphyry $\mathrm{Cu}$ deposits, it is fluid cooling over the $\sim 550$ to $350{ }^{\circ} \mathrm{C}$ range, assisted 
by fluid-rock interaction, that is largely responsible for precipitation of the $\mathrm{Cu}$, in low sulfidation state $\mathrm{Cu}-\mathrm{Fe}$ sulfide assemblages, plus any Au" (Sillitoe, 2010). Abundant Fe in porphyry magmas is leached at high to moderately high temperatures by fluids and forms hydrothermal magnetite (Seedorff and Einaudi, 2004). In fact, hydrothermal magnetite is an indicator for porphyry deposits (Sillitoe, 2010). Therefore, the reaction of $\mathrm{Fe}$ must occur mainly in fluids, i.e., oxidation of $\mathrm{FeCl}_{2}$. (2) Anhydrite (not $\mathrm{H}_{2} \mathrm{SO}_{4}$ ) is the dominant sulfate species in oxidized porphyry magmas (Jugo, 2009; Liang et al., 2009). Nevertheless, sulfate is quite soluble in fluids under high pressures and temperatures, with a partition coefficient of about 50 between fluids and melts (Keppler, 2010). Therefore, the $\mathrm{SO}_{4}{ }^{2-}$ concentration might be reasonably high in magmatic fluids. (3) As emphasized by Pokrovski (2013), the near-neutral $\mathrm{pH}$ value during potassic alteration does not allow abundant $\mathrm{H}^{+}$. (4) Ferrous iron reacts with $\mathrm{H}_{2} \mathrm{~S}$, releasing $\mathrm{H}^{+}$(Eq. (6)), which tends to lower $\mathrm{pH}$ and correspondingly increases the oxidation potential of sulfate. $\mathrm{H}_{2} \mathrm{~S}$ is not the main final species in porphyry mineralization, it forms sulfides. Therefore, we believe that reactions listed in (Sun et al., 2013) better describe the process that is reflected in the mineralogy.

In his comment, Pokrovski (2013) proposes that the oxygen fugacity may be driven across the $\mathrm{HM}$ buffer by the oxidation of $\mathrm{H}_{2} \mathrm{~S}$ to $\mathrm{SO}_{2}$ (Fig. 1, Eq. (13)). $\mathrm{H}_{2} \mathrm{~S}$, however, reacts with $\mathrm{SO}_{2}$, forming $\mathrm{S}$ (Eq. (14)), which is not observed in any porphyry deposits. For the same reason, reaction 7 of Pokrovski (2013) is not likely to be of any significance for porphyry mineralization. $\mathrm{SO}_{2}$ is indeed abundant during degassing of volcanic rocks and epithermal mineralization, which usually have abundant $\mathrm{S}$. The two references cited by Pokrovski (2013) describe transitions from porphyry to epithermal environments (Einaudi et al., 2003; Heinrich, 2005). High pressure experiments show that sulfate is the dominant sulfur species in magmas under high oxygen fugacity (Jugo et al., 2010).

$\mathrm{H}_{2} \mathrm{~S}+1.5 \mathrm{O}_{2}=\mathrm{SO}_{2}+\mathrm{H}_{2} \mathrm{O}$

$2 \mathrm{H}_{2} \mathrm{~S}+\mathrm{SO}_{2}=3 \mathrm{~S}+2 \mathrm{H}_{2} \mathrm{O}$

Pokrovski (2013) claimes that $\mathrm{HCl}(\mathrm{aq})$ cannot change the acidity dramatically because it is a weak acid at temperatures $>500{ }^{\circ} \mathrm{C}$. Interestingly, he cited Tagirov et al. (1997), which reports experiments between $350-500{ }^{\circ} \mathrm{C}$. The $\log \mathrm{K}_{\mathrm{d}}$ of $\mathrm{HCl}$ is about -4 at $500{ }^{\circ} \mathrm{C}$, which indicates the $\mathrm{pH}$ value is 4 for $1 \mathrm{M} \mathrm{HCl}$. The higher the $\mathrm{HCl}$ concentrations, the lower the $\mathrm{pH}$. Note, porphyry $\mathrm{Cu}$ mineralization usually occurs at temperatures of $\sim 550$ to $350{ }^{\circ} \mathrm{C}$ (Sillitoe, 2010). The $\log \mathrm{K}_{\mathrm{d}}$ of $\mathrm{HCl}$ is higher than 2 at $350{ }^{\circ} \mathrm{C}$. Reactions (10) and (11) of Pokrovski (2013) are sound to us, although we prefer Eqs. (6) and (15), respectively. The point is that $\mathrm{H}_{2}$ does not necessarily react with $\mathrm{O}_{2}$ (Eq. (8)). It may react with $\mathrm{CO}_{2}$ (Eq. (7)) and/or also escape from the system during degassing. Nevertheless, the $\mathrm{H}^{+}$formed during the formation of sulfide explains many important features of porphyry deposits, e.g., extremely low $\mathrm{pH}$ fluid responsible for the high degrees of base leaching involved in advanced argillic lithocap formation (Sillitoe, 2010) and alteration (Eqs. (16)-(21)).
$\mathrm{Cu}^{+}+\mathrm{Fe}^{2+}+2 \mathrm{H}_{2} \mathrm{~S}=\mathrm{CuFeS}_{2}+3 \mathrm{H}^{+}+1 / 2 \mathrm{H}_{2}$

We agree with Pokrovski (2013) that quantitative knowledge of the thermodynamic reaction constants between sulfur- and iron-bearing forms and mineral solubilities in the temperature and pressure range of porphyry systems will improve our understanding on the role of $\mathrm{S}_{3}{ }^{-}$in the redox and acidity control during porphyry deposit formation. As we mentioned at the beginning, porphyry deposits are complicated with a variety of alteration mechanisms (e.g., Eqs. (1)-(21)). In addition to the behavior of $\mathrm{S}_{3}{ }^{-}$, alteration reactions also need to be quantitively studied in the future. These, however, do not affect the observed coupling between sulfate reduction and magnetite-hematite crystallization.

$$
\begin{aligned}
& 2 \mathrm{~K}(\mathrm{Mg}, \mathrm{Fe})_{3} \mathrm{AlSi}_{3} \mathrm{O}_{10}(\mathrm{OH})_{2}+4 \mathrm{H}^{+}=\mathrm{Al}(\mathrm{Mg}, \mathrm{Fe})_{5} \\
& \mathrm{AlSi}_{3} \mathrm{O}_{10}(\mathrm{OH})_{8}+(\mathrm{Mg}, \mathrm{Fe})^{2+}+2 \mathrm{~K}^{+}+3 \mathrm{SiO}_{2} \\
& 3 \mathrm{KAlSi}_{3} \mathrm{O}_{8}+2 \mathrm{H}^{+}=\mathrm{KAl}_{2} \mathrm{Si}_{3} \mathrm{AlO}_{10}(\mathrm{OH})_{2}+2 \mathrm{~K}^{+} \\
& +6 \mathrm{SiO}_{2} \\
& 3 \mathrm{NaAlSi}_{3} \mathrm{O}_{8}+2 \mathrm{~K}^{+}+\mathrm{H}^{+}+\mathrm{H}_{2} \mathrm{O}=\left(\mathrm{K}, \mathrm{Na}, \mathrm{H}_{2} \mathrm{O}\right) \\
& \mathrm{Al}_{2}(\mathrm{Al}, \mathrm{Si}) \mathrm{Si}_{3} \mathrm{O}_{10}(\mathrm{OH})_{2}+6 \mathrm{SiO}_{2}+3 \mathrm{Na}^{+} \\
& 2 \mathrm{KAl}_{3} \mathrm{Si}_{3} \mathrm{O}_{10}(\mathrm{OH})_{2}+2 \mathrm{H}^{+}+3 \mathrm{H}_{2} \mathrm{O}=3 \mathrm{Al}_{2} \mathrm{Si}_{2} \mathrm{O}_{5}(\mathrm{OH})_{4} \text {, } \\
& +2 \mathrm{~K}^{+} \\
& \mathrm{KFe}_{3} \mathrm{AlSi}_{3} \mathrm{O}_{10}(\mathrm{OH})_{2}+1 / 2 \mathrm{O}_{2}=\mathrm{KAlSi}_{3} \mathrm{O}_{8} \\
& +\mathrm{Fe}_{3} \mathrm{O}_{4}+\mathrm{H}_{2} \mathrm{O} \\
& \mathrm{CaAl}_{2} \mathrm{Si}_{2} \mathrm{O}_{8}+2 \mathrm{KCl}+4 \mathrm{SiO}_{2}=2 \mathrm{KAlSi}_{3} \mathrm{O}_{8}+\mathrm{CaCl}_{2}
\end{aligned}
$$

We would like to point out that oxygen fugacity is sometimes misleading, because it is controlled by temperature, pressure, concentrations (Fig. 1) and in some cases, $\mathrm{pH}$ values (i.e., concentration of $\mathrm{H}^{+}$). Moreover, some oxidationreduction processes do not have any oxygen evolved (e.g., Eqs. (6) and (15)). For this reason, we also used the oxidation potential in Sun et al. (2013) to better explain our model. Fluids are essential for porphyry mineralization (Sillitoe, 2010) with most of the reactions occurring in fluids and/or during fluid/rock interactions, which is often ignored when discussing porphyry mineralization. Most importantly, reactions must be compatible with geological observations.

\section{ACKNOWLEDGMENT}

The study is supported by "Strategic Priority Research Program (B)" of the Chinese Academy of Sciences (No. XDB03010302) and National Natural Science Foundation of China (Nos. 41090374, 41121002, 41172080). GIG Contribution No. 1714.

\section{REFERENCES}

Ballard J. R., Palin J. M. and Campbell I. H. (2002) Relative oxidation states of magmas inferred from $\mathrm{Ce}(\mathrm{IV}) / \mathrm{Ce}(\mathrm{III})$ in zircon: application to porphyry copper deposits of northern Chile. Contrib. Mineral. Petrol. 144, 347-364.

Einaudi M. T., Hedenquist J. W. and Esra Inan E. (2003) Sulfidation state of fluid in active and extinct hydrothermal 
systems: transitions from porphyry to epithermal environments. Soc. Econ. Geol. Spec. Publ. 10, 285-313.

Heinrich C. A. (1990) The chemistry of hydrothermal tin (-tungsten) ore deposition. Econ. Geol. 85, 457-481.

Heinrich C. A. (2005) The physical and chemical evolution of lowsalinity magmatic fluids at the porphyry to epithermal transition: a thermodynamic study. Miner. Deposita 39, 864-889.

Jenner F. E., O'Neill H. S. C., Arculus R. J. and Mavrogenes J. A. (2010) The magnetite crisis in the evolution of arc-related magmas and the initial concentration of $\mathrm{Au}, \mathrm{Ag}$ and $\mathrm{Cu} . J$. Petrol. 51, 2445-2464.

Jugo P. J. (2009) Sulfur content at sulfide saturation in oxidized magmas. Geology 37, 415-418.

Jugo P. J., Wilke M. and Botcharnikov R. E. (2010) Sulfur K-edge XANES analysis of natural and synthetic basaltic glasses: implications for $\mathrm{S}$ speciation and $\mathrm{S}$ content as function of oxygen fugacity. Geochim. Cosmochim. Acta 74, 5926-5938.

Keppler H. (2010) The distribution of sulfur between haplogranitic melts and aqueous fluids. Geochim. Cosmochim. Acta 74, 645660.

Liang H. Y., Campbell I. H., Allen C., Sun W. D., Liu C. Q., Yu H. X., Xie Y. W. and Zhang Y. Q. (2006) Zircon $\mathrm{Ce}^{4+} / \mathrm{Ce}^{3+}$ ratios and ages for Yulong ore-bearing porphyries in eastern Tibet. Mineral. Deposita 41, 152-159.

Liang H. Y., Sun W. D., Su W. C. and Zartman R. E. (2009) Porphyry copper-gold mineralization at Yulong, China, promoted by decreasing redox potential during magnetite alteration. Econ. Geol. 104, 587-596.

Matthews S. J., Jones A. P. and Beard A. D. (1994) Buffering of melt oxygen fugacity by sulfur redox reactions in calc-alkaline magmas. J. Geol. Soc. Lond. 151, 815-823.

Mungall J. E. (2002) Roasting the mantle: slab melting and the genesis of major $\mathrm{Au}$ and $\mathrm{Au}$-rich $\mathrm{Cu}$ deposits. Geology 30, 915918.

Pokrovski G. S. (2013) Use and misuse of chemical reactions and aqueous species distribution diagrams for interpreting metal transport and deposition in porphyry copper systems: Comment on Sun et al. (2013) "The link between reduced porphyry copper deposits and oxidized magmas". Geochim. Cosmochim. Acta.

Pokrovski G. S. and Dubrovinsky L. S. (2011) The $\mathrm{S}_{3}{ }^{-}$ion is stable in geological fluids at elevated temperatures and pressures. Science 331, 1052-1054.

Seedorff E. and Einaudi M. T. (2004) Henderson porphyry molybdenum system, Colorado: II. Decoupling of introduction and deposition of metals during geochemical evolution of hydrothermal fluids. Econ. Geol. Bull. Soc. Econ. Geol. 99, 3972 .
Sillitoe R. H. (1997) Characteristics and controls of the largest porphyry copper-gold and epithermal gold deposits in the circum-Pacific region. Aust. J. Earth Sci. 44, 373-388.

Sillitoe R. H. (2010) Porphyry copper systems. Econ. Geol. 105, 3-41. Sun W. D., Arculus R. J., Kamenetsky V. S. and Binns R. A. (2004) Release of gold-bearing fluids in convergent margin magmas prompted by magnetite crystallization. Nature 431, 975-978.

Sun W. D., Liang H. Y., Ling M. X., Zhan M. Z., Ding X., Zhang H., Yang X. Y., Li Y. L., Ireland T. R., Wei Q. R. and Fan W. M. (2013) The link between reduced porphyry copper deposits and oxidized magmas. Geochim. Cosmochim. Acta 103, 263275.

Sun W. D., Ling M. X., Chung S. L., Ding X., Yang X. Y., Liang H. Y., Fan W. M., Goldfarb R. and Yin Q. Z. (2012a) Geochemical constraints on adakites of different origins and copper mineralization. J. Geol. 120, 105-120.

Sun W. D., Ling M. X., Ding X., Chung S. L., Yang X. Y. and Fan W. M. (2012b) The genetic association of adakites and $\mathrm{Cu}-\mathrm{Au}$ ore deposits: a reply. Int. Geol. Rev. 54, 370-372.

Sun W. D., Ling M. X., Yang X. Y., Fan W. M., Ding X. and Liang H. Y. (2010) Ridge subduction and porphyry coppergold mineralization: an overview. Sci. China Earth Sci. 53, 475 484.

Sun W. D., Zhang H., Ling M. X., Ding X., Chung S. L., Zhou J. B., Yang X. Y. and Fan W. M. (2011) The genetic association of adakites and $\mathrm{Cu}-\mathrm{Au}$ ore deposits. Int. Geol. Rev. 53, 691703.

Tagirov B. R., Zotov A. V. and Akinfiev N. N. (1997) Experimental study of dissociation of $\mathrm{HCl}$ from 350 to 500 degrees $\mathrm{C}$ and from 500 to 2500 bars: thermodynamic properties of $\mathrm{HCl}(\mathrm{aq})$ degrees. Geochim. Cosmochim. Acta 61, 4267-4280.

Zajacz Z., Candela P. A., Piccoli P. M., Walle M. and SanchezValle C. (2012) Gold and copper in volatile saturated mafic to intermediate magmas: solubilities, partitioning, and implications for ore deposit formation. Geochim. Cosmochim. Acta 91, $140-159$.

Zajacz Z., Seo J. H., Candela P. A., Piccoli P. M. and Tossell J. A. (2011) The solubility of copper in high-temperature magmatic vapors: a quest for the significance of various chloride and sulfide complexes. Geochim. Cosmochim. Acta 75, 2811-2827.

Zhang H., Ling M. X., Liu Y. L., Tu X. L., Wang F. Y., Li C. Y., Liang H. Y., Yang X. Y., Arndt N. T. and Sun W. D. (2013) High oxygen fugacity and slab melting linked to $\mathrm{Cu}$ mineralization: evidence from Dexing porphyry copper deposits, Southeastern China. J. Geol. 121, 289-305.

Associate editor: Edward Ripley 